\title{
PENGARUH YOUTUBE ADVERTISING TERHADAP RESPONS KONSUMEN
}

\author{
Arief Pratama $^{1}$, Rosita Anggraeni ${ }^{2}$ \\ ${ }^{1}$ Sekolah Tinggi Ilmu Komunikasi Inter Studi \\ Jl Wijaya II No 62 Jakarta 12160 \\ pratamaariefman@gmail.com \\ ${ }^{2}$ Sekolah Tinggi Ilmu Komunikasi Inter Studi \\ Jl Wijaya II No 62 Jakarta 12160 \\ rosita.tagor@gmail.com
}

\begin{abstract}
ABSTRAK
Tujuan penelitian ini adalah untuk mengetahui pengaruh youtube advertising terhadap respons konsumen. Teori yang di gunakan adalah teori advertising value (informativeness, credibility, entertainment, irritation) dan teori respons konsumen (awareness, knowledge, liking, preference, conviction, purchase). Pendekatan dalam penelitian ini adalah kuantitatif, sedangkan metode penelitiannya survei dengan jenis penelitian eksplanatif. Populasi dalam penelitian ini 344 orang adalah mahasiswa STIKOM Interstudi tahun angkatan 2016-2017. Untuk menentukan ukuran sampel menggunakan rumus Slovin berjumlah 100 orang responden. Teknik pengumpulan data dilakukan dengan kuesioner pertanyaan tertutup, observasi, kepustakaan, dan studi literatur. Sedangkan teknik analisis data dilakukan melalui tahap pengolahan data secara SPSS, analisis data dengan rumus statistik dan mengintrepresaikannya. Hasil penelitian ini adalah pengaruh antara youtube advertising terhadap respons konsumen menunjukan hasil yang kuat.
\end{abstract}

Kata Kunci: Youtube advertising, Advertising Value, dan Respons Konsumen

\begin{abstract}
The purpose of this research is to study YouTube advertising research on consumer responses. The theory used is the theory of advertising value (informativeness, credibility, entertainment, irritation) and consumer response theory (awareness, knowledge, preferences, preferences, beliefs, purchases). This research is quantitative, while the research method is a survey with a type of explanatory research. The population in this study 344 people were students of STIKOM Interstudi year 2016-2017. To determine the sample size using the Slovin formula, collecting 100 respondents. The technique of answering data is done by closed question questionnaire, observation, literature, and literature study. While the data analysis technique is done by processing data using SPSS, analyzing data with statistical formulas and interpreting them. The results of this study are among YouTube advertisements on consumer responses showing strong results.
\end{abstract}

Keywords: Youtube Advertising, Advertising Value, Consumer Responses 


\section{PENDAHULUAN}

Saat ini perkembangan teknologi informasi dan komunikasi sudah sangat berkembang pesat membuat persaingan bisnis menjadi ketat. Seiring berkembangnya zaman, lahirlah Internet atau media sosial sebagai media penyebaran informasi baru yang mampu menjangkau seluruh dunia (Dominick, 2008). Saat ini, semua orang antusias dengan keberadaan media sosial seperti YouTube, Facebook, dan Twitter, yang terkenal sebagai wadah untuk menunjukkan diri secara digital dan tempat untuk membangun hubungan sosial (Lyons, 2012). Hal ini yang membuat teknologi internet menjadi sebuah media yang baru yang bisa memenuhi kebutuhan promosi iklan. Salah satu media di internet yang bisa memenuhi kebutuhan promosi iklan adalah media sosial.

Media sosial sendiri memiliki arti sebagai media online yang mengijinkan para penggunanya untuk melakukan aktivitas sosial antar sesama pengguna. Salah satu dari media sosial adalah YouTube.YouTube merupakan situs untuk menonton dan berbagi video yang menyediakan berbagai macam video mulai dari video klip sampai film, serta video-video yang dibuat oleh pengguna YouTube sendiri secara gratis. YouTube adalah sebuah tempat dimana konten iklan, amatiran, nirlaba, pemerintahan, sekolahan dan aktivis mampu jalan berdampigan dan saling berinteraksi dengan cara yang lebih kompleks dari sebelumnya (Jenkins, 2007) YouTube saat ini telah menjadi market leader di kategori website video-sharing (Pace, 2008, pp. 213-226).

YouTube dianggap sebagai ruang berbasis fantasi yang memberikan masyarakat kebebasan untuk mengekspresikan pandangan mereka dan menjadi apapun atau siapapun yang mereka inginkan tanpa memandang ras, jenis kelamin, usia dan tubuh (Lange, 2007, pp. 13-21). Manfaat YouTube bagi pelaku bisnis online untuk mempromosikan produk mereka, yaitu dengan cara mengunggah video tersebut ke YouTube sebagai sarana iklan. Hal inilah yang menjadi daya tarik pelaku bisnis untuk menggunakan media internet YouTube sebagai sarana untuk mengiklankan produknya di YouTube.

Terdapat beberapa format yang disediakan oleh YouTube terkait dengan preferensi masing masing pemasang iklan. Display ads memasangkan iklan dari sebuah produk di samping kanan video, overlay ads diletakkan dalam video yang berupa banner kecil, skippable video ads merupakan iklan yang diputar sebelum memulai video dan dapat di skip atau tidak ditonton tergantung keinginan pengguna YouTube, non-skippable video ads dan long non-skippable video ads iklan tidak dapat diskip dan berdurasi antara $15-30$ detik, dan terakhir adalah sponsored cards iklan disesuaikan dengan video yang telah ditonton oleh konsumen dari segi produk yang terdapat dalam video tersebut.

Metode inilah yang sering digunakan oleh para perusahaan dan dinilai cukup efektif untuk mendapatkan respons konsumen,sehingga mereka mengenal produk atau jasa yang ditawarkan. Respons konsumen merupakan hal terpenting dari sebuah iklan, pemasar tentu menginginkan iklan mereka mampu memengaruhi konsumen untuk melakukan suatu respons positif yang diharapkan.Salah satu pemasar iklan yang memilih YouTube sebagai sarana untuk berkampanye adalah situs jual beli online Shopee.Menurut hasil dari survei Google, peningkatan YouTube Indonesia dari tahun ke tahun mencapai $600 \%$ berdasarkan data kuartal ketiga 2015 dibandingkan tahun sebelumnya. 
Pertumbuhan itu lebih besar tiga kali lipat dari negara lain di Asia Pasifik. Selain jumlah video, durasi menonton video di YouTube Indonesia bertambah panjang. Dibandingkan kuartal ketiga 2015, durasi menonton meningkat $130 \%$ tahun ini. Lagi-lagi, Indonesia menjadi negara dengan pertumbuhan tercepat di Asia Pasifik. Selain itu, sepuluh konten YouTube yang paling banyak ditonton di Indonesia, yakni musik di posisi pertama, disusul oleh tutorial, komedi, trailer film, film asing, User Generated Content, pendidikan, hiburan, sepak bola dan gaya hidup.

Menurut survei Google, jumlah penonton video di YouTube via smartphone melebihi jumlah penonton video YouTube via komputer sekitar $60 \%$. Artinya penonton YouTube di Indonesia memang sering mengakses streaming video lewat smartphone daripada menonton lewat komputer atau laptop. Diperkirakan 90 juta masyarakat Indonesia sudah online dan menjadikan Indonesia sebagai negara yang aktif terkoneksi Internet dengan penetrasi $43 \%$ di smartphone dibandingkan di komputer yang hanya $15 \%$.

Salah satu produsen yang beriklan melalui YouTube adalah Situs Jual Beli Shopee.Situs ini merupakan produk di bawah SEA Group (sebelumnya dikenal sebagai Garena). Prestasi marketplace ini adalah keberhasilan promosi yang dalam waktu singkat, pengguna shopee tidak kalah banyak dari para pesaingnya. Tokoh penting di balik Sejarah Shopee adalah Chris Feng pendiri dan CEO yang juga merupakan lulusan terbaik dari Universitas Singapura.Shopee memudahkan para penjual serta pembeli dalam berinteraksi melalui fitur live chatnya. Situs Shopee juga menyajikan desain website yang menarik dengan pemilihan warna layout yang atraktif. Para pengguna internet yang berselancar ke situs ini pasti tertarik untuk melihat-lihat apa yang disajikan dan ditawarkan oleh situs ini. Apalagi ketika melihat display produk yang menarik dan tag aneka diskon dan voucher belanja. Merelakan sedikit waktu untuk membuka kategori produk pasti tak masalah. Terdapat bermacam-macam kategori produk pada situs Shopee yakni fashion, beauty \& health, babies \& kids, home \& garden, gadget \& computer, hobby dan service \& food.

$$
\text { Pada tahun 2018,Situs Shopee }
$$
mengeluarkan iklan di youtube dengan judul "Belanja di Shopee pasti hepi" yang melibatkan selebrita Via Vallen sebagai endorser di video tersebut. sehingga diharapkan kredibilitas iklan dan minat beli bertambah.Persaingan di dunia Industri E-commerce Indonesia sedang berkembang dengan banyaknya penyedia jasa Jual Beli Online. Para produsen menggunakan berbagai cara untuk mempromosikan produknya, agar mencapai iklan yang efektif maka jasa Ecommerce harus memahami bagaimana perilaku konsumen sehingga dapat timbul respons dari konsumen yang telah menjadi sasaran produsen.

Youtube merupakan salah satu media internet yang dapat di gunakan oleh jasa Ecommerce untuk mempromosikan produknya, hal ini di karenakan daya jangkau Youtube yang luas dan dapat menjelaskan kelebihan dari produk secara lebih menarik sehingga apa yang ingin di sampaikan dalam iklan tersebut dapat diterima dengan baik oleh calon konsumennya.Shopee juga melakukan kegiatan promosi melalui media televisi mengingat persaingan toko online di Indonesia sesak.Dengan beriklan di Youtube dan Televisi strategi ini di anggap efektif karena memiliki sirkulasi yang sangat luas,dan dapat mempengaruhi khalayak massa dalam meningkatkan Respons Konsumen. 
Dari penuturan di atas, maka peneliti tertarik untuk mengambil judul adakah Pengaruh Youtube Advertising terhadap Respons Konsumen (Survei Eksplanatif Tentang Iklan YouTube Situs Shopee Belanja di Shopee pasti hepi versi "Goyang shopee" Terhadap Respons Konsumen di Kalangan Mahasiswa STIKOM Interstudi angkatan 2016-2017).

\section{KERANGKA PEMIKIRAN}

\section{Periklanan}

Periklanan menurut (Kotler P. , 2005, p. 277), didefinisikan sebagai segala bentuk penyajian non-personal dan promosi ide, barang, atau jasa oleh suatu sponsor tertentu yang memerlukan pembayaran. Periklanan merupakan sarana promosi yang sangat ekspresif. Sarana ini memungkinkan perusahaan untuk mendramatisir produknya dengan menggunakan beragam seni visualisasi, cetakan, musik, dan warna-warna yang menarik. Periklanan pun turut berperan penting dalam pembangunan sebuah citra produk untuk jangka panjang.

Secara umum, iklan merupakan promosi terhadap barang, jasa maupun ide yang harus dibayarkan oleh sponsor. Fungsi penting dilakukannya periklanan oleh sponsor menurut (Shimp, 2003, p. 357) antara lain: (1) Informing, periklanan mampu meningkatkan kesadaran konsumen akan merek-merek baru, serta memberikan informasi mengenai berbagai fitur dan benefit dari merek tersebut, serta memfasilitasi penciptaan citra merek yang positif, (2) Persuading, iklan dianggap berhasil apabila mampu mempersuasi (membujuk) pelanggan untuk melakukan apa yang diinginkan oleh pengiklan, seperti mencoba atau mencicipi produk dan jasa yang diiklankan, (3) Persuading, iklan dianggap berhasil apabila mampu mempersuasi (membujuk) pelanggan untuk melakukan apa yang diinginkan oleh pengiklan, seperti mencoba atau mencicipi produk dan jasa yang diiklankan, (4) Adding Value, periklanan mampu memberikan nilai tambah kepada sebuah merek dengan mempengaruhi persepsi konsumen terhadap merek tersebut. Periklanan yang efektif akan mampu menciptakan persepsi positif konsumen terhadap suatu merek, seperti merek dipandang elegan, bergengsi, ataupun lebih unggul dibandingkan merek pesaing, (5) Assisting, periklanan turut berperan dalam membantu perwakilan penjualan dari suatu merek. Maksudnya ialah, periklanan mampu menjadi pendamping yang memberikan fasilitas berupa upaya-upaya dari perusahaan dalam proses komunikasi pemasaran. Seperti, meluncurkan promosi-promosi penjualan seperti kupon dan undian berhadiah.

Terdapat beberapa tujuan utama periklanan menurut Phil. Astrid. S. Susanto yang dikutip oleh (Soemanegara, 2006, p. 49), yaitu menumbuhkan perasaan tertentu dalam diri komunikan, rasa suka maupun tidak suka, terhadap barang, jasa maupun ide dengan memberikan persepsi kepada komunikan dan meyakinkan komunikan akan sebuah kebenaran tentang apa yang dianjurkan dalam sebuah iklan dan membuat konsumen memiliki rasa ingin memiliki atau menggunakan barang mauapun jasa tersebut.

\section{Iklan}

Iklan (Advertising) berasal dari Bahasa Yunan, yang artinya adalah "menggiring orang pada sebuah gagasan”. Pengertian iklan secara umum adalah segala bentuk pesan promosi terhadap suatu barang, jasa, dan ide yang disampaikan melalui media berbayar dan 
dibayarkan oleh sponsor tertentu dan ditunjukkan kepada sebagian besar masyarakat. Menurut (Suhandang K. , 2010, p. 13), periklanan adalah suatu proses komunikasi massa yang melibatkan sponsor tertentu, yaitu sang pengiklan, yang membayar jasa dari sebuah media massa atas penyiaran iklannya. (Kotler P. , 2002, p. 277) mengartikan periklanan sebagai sebuah penyajian dan promosi atas sebuah barang, ide, dan jasa secara non-personal oleh suatu sponsor tertentu yang memerlukan pembayaran.Iklan didefinisikan sebagai bentuk komunikasi non-personal yang menawarkan pesan-pesan yang bersifat persuasif dari sponsor berbayar untuk mempengaruhi sesorang untuk melakukan pembelian terhadap suatu produk dan dengan membayar sejumlah biaya untuk media (Kriyantono R. , 2008, p. 174). Dengan demikian, iklan dapat didefinisikan sebagai suatu komunikasi nonpersonal dan bersifat komersial mengenai sebuah organisasi yang menawarkan barang, jasa, maupun ide dan ditransmisikan kepada khalayak melalui media massa seperti televisi, radio, koran, majalah, reklame ruang luar, ataupun kendaraan umum (Lee \& Carla, 2004).

Menurut Liliweri, iklan memiliki beberapa fungsi utama yaitu: (1) Iklan sebagai fungsi pemasaran, (2) Iklan sebagai fungsi komunikasi, (3) Iklan sebagai fungsi pendidikan, (4) Iklan sebagai fungsi social, (4) Iklan sebagai fungsi ekonomi.

Sebagai media penyampaian pesan, iklan memiliki dua jenis utama menurut (Lamb, 2001, p. 205)yaitu: (1) Periklanan Institusi (Institutional Advertising), Periklanan institusi didesain untuk membentuk dan meningkatkan citra positif sebuah perusahaan dibandingkan untuk mempromosikan produk, barang, atau jasa yang dimiliki. Bentuk dari periklanan institusi dikenal dengan advocacy advertisin, (2) Periklanan Produk, Periklanan produk sesuai dengan sebutannya, digunakan untuk mempromosikan benefit dan fitur dari suatu barang, jasa, dan ide tertentu.

\section{Iklan Internet}

Iklan internet ialah salah satu periklanan yang saat ini sedang hangat diperbincangkan dan banyak digunakan oleh perusahaan-perusahaan dalam mempromosikan produk mereka. Internet sudah bukan lagi menjadi sesuatu yang asing untuk masyarakat Indonesia, meningkatnya pengguna internet membuat para pemasang iklan mengambil kesempatan untuk menempatkan iklannya pada website publisher yang dianggap potensial. Internet memberikan pengaruh secara radikal dan besar mengenai bagaimana perusahaan mampu mengkomunikasikan produk mereka kepada pelanggan dan membangun hubungan yang baik (Sumarwan, 2011).

Media sosial merupakan sebuah sarana yang diciptakan untuk memudahkan interaksi sosial dari penggunanya. Dengan segala kemudahan yang telah diberikan oleh media sosial tersebut, penyebaran informasi menjadi sangat mudah. Media sosial merupakan sebuah kelompok aplikasi berbasis internet yang membangun diatas dasar ideologi dan teknologi Web 2.0 dan yang memungkinkan penciptaan dan pertukaran usergenerated content (Kaplan \& Haenlein, 2010).

Saat ini perkembangan teknologi internet dan mobile phone sangatlah pesat, maka dari itu media sosial pun turut berkembang dengan pesat. Berkembangnya teknologi internet dan mobile phone tersebutlah yang memudahkan masyarakat dalam mengakses jejaring sosial seperti Facebook, Twitter, dan YouTube misalnya, yang merupakan jejaring sosial terbesar. Pengaksesan tersebut dapat 
dilakukan dimana saja dan kapan saja dengan menggunakan ponsel pintar. Hal ini yang mengakibatkan terjadinya fenomena yang besar terhadap arus informasi. Masyarakat dapat menerima informasi ataupun berita mengenai apapun dan darimana saja. Fenomena ini berdampak besar terhadap surutnya penggunaan dan peran media massa konvensional dalam kehidupan seharihari.

Iklan berbentuk video yang muncul sesudah, sebelum, atau saat sebuah konten video sedang diakses (Laudon dan Traver, 2014). Pengunjung sebuah website atau penonton yang sedang menonton sebuah video secara online menghadapi berbagai format dari online video adS dengan pre-roll ads menjadi yang paling sering digunakan (Moriarty, 2015).

Online video ads dapat ditemukan ketika penonton sedang streaming sebuah video online.Streaming video secara online yang menyaksikan berbagai program seperti acara televisi, film layar lebar, hingga unggahan video pribadi (YouTube) dapat diakses secara bebas melalui internet dari tablet dan smartphone (Moriarty, 2015).

YouTube merupakan sebuah alat untuk video sharing dengan tujuan agar pengguna dapat mengunggah sebuah video serta menyaksikan video yang berasal dari pengguna lain (Christensson, 2009). YouTube advertising merupakan format dari online video advertising yang baru dan sedang dikembangkan, memiliki karateristik TV dan media sosial serta berbeda dengan format beriklan tradisional (Dehghani, 2016, pp. 165-172). YouTube menampilkan berbagai tipe video yang memungkinkan sebuah brand untuk ditampilkan lebih menonjol tetapi pelanggan susah untuk mengingat kembali informasi produk yang diiklankan, sehingga peran brand menjadi esensial.

\section{Perilaku Konsumen}

Perilaku konsumen didefinisikan sebagai studi tentang unit pembelian (buying units) dan proses pertukaran yang melibatkan perolehan, konsumsi, dan pembuangan barang, jasa, pengalaman,serta ide-ide (Mowen, 2002).

Dalam batasan ini perilaku konsumen meliputi semua tindakan yang dilakukan oleh seseorang untuk mencari, membeli, menggunakan, mengevaluasi dan menghabiskan produk. Dalam kegiatan mencari, tentu bukan terbatas dalam mencari barang atau jasa yang dibutuhkan, melainkan juga mencari informasi yang terkait dengan barang atau jasa yang dibutuhkan dan diinginkan.

Menurut Engel Blackwell dan Miniard, perilaku konsumen sebagai tindakan yang terlibat secara langsung dalam memperoleh, mengkonsumsi dan menghabiskan suatu produk atau jasa termasuk proses keputusan yang mendahului dan mengikuti tindakan-tindakan tersebut (Nitisusastro, 2012).

Sedangkan menurut Hawkins, Best dan Coney perilaku konsumen merupakan studi tentang bagaimana individu, kelompok atau organisasi melakukan proses pemilihan, pengamanan, dan penghentian produk, jasa pengalaman atau ide untuk memuaskan kebutuhannya terhadap konsumen dan masyarakatMenurut Kotler (2003), menyatakan tahapan-tahapan yang di lakukan oleh konsumen dalam perilaku konsumen meliputi: mengenali permasalahan, mencari informasi, mengevaluasi 
beberapa pilihan, keputusan membeli, perilaku pasca membeli.

Menurut Wilkie (1990), tipe perilaku konsumen dalam melakukan pembelian dibagi menjadi empat berdasarkan tingkat keterlibatan pembeli dan tingkat keterlibatan diferensiasi merek, yaitu (1) Pengalokasian budget adalah Pilihan konsumen terhadap suatu barang dipengaruhi oleh cara bagaimana membelanjakan atau menyimpan dana yang tersedia, kapan waktu yang tepat untuk membelanjakan uang dan apakah perlu melakukan pinjaman untuk melakukan pembelian, (2) Membeli produk atau tidak adalah Perilaku pembelian yang menggambarkan pilihan yang dibuat oleh konsumen, berkenan dengan tiap kategori produk atau jasa itu sendiri, (3) Pemilihan tempat untuk mendapatkan produk adalah Perilaku pembelian berdasarkan pilihan konsumen, berdasarkan tempat atau di mana konsumen akan melaksanan pembelian produk atau jasa tersebut, (4) Keputusan atas merek dan gaya adalah Pilihan konsumen untuk memutuskan secara terperinci mengenai produk apa yang sebenarnya ingin dibeli.

\section{Respons Konsumen}

Mengevaluasi hasil akhir dari penyampaian sebuah iklan merupakan aspek terpenting dari keseluruhan proses pengiklanan. Untuk mengetahui efektivitas sebuah komunikasi pemasaran, dapat dirumuskan dengan melihat Respons dari audiens. Respons dimengerti sebagai reaksi terhadap stimuli. Stimulus adalah segala bentuk informasi yang ditangkap oleh panca indera (penglihatan, pendengaran, penciuman, perasa, dan perabaan). Hubungan dari pembuatan sebuah iklan dan pemilihan media sangatlah erat dalam menghasilkan respons konsumen. Setiap respons dari konsumen pasti melewati 3 tingkatan yaitu: tingkat kognitif, afektif dan keperilakuan (behavior).

Respons adalah suatu evaluasi menyeluruh yang memungkinkan seseorang bertindak dengan cara yang benefitial maupun unbenefitial secara konsisten dan kontinual berhubungan dengan suatu objek seperti produk, jasa maupun ide (Engel, Blackwell, \& Miniard, 1994). Respons konsumen akan timbul apabila ada sesuatu yang merangsang indera dari seorang konsumen. Response process atau proses Respons merupakan aspek terpenting dari sebuah komunikasi pemasaran, dimana dapat dilihat dan diukurnya dampak pada perilaku spesifik konsumen seperti pembelian suatu produk.Respons berkaitan erat dengan efek sebab akibat dari suatu peristiwa, dimana Respons muncul apabila seseorang menangkap, menginterpretasi dan menghargai sebuah produk, jasa, maupun ide yang dihadapinya (Soerjabrata, 1980, p. 143).Ada tiga tahapan Respons yang diharapkan oleh audiens sebagai calon konsumen, yaitu: (Engel, Blackwell, \& Miniard, 1995).

Respons berkaitan erat dengan efek sebab akibat dari suatu peristiwa, dimana Respons muncul apabila seseorang menangkap, menginterpretasi dan menghargai sebuah produk, jasa, maupun ide yang dihadapinya (Soerjabrata, 1980, p. 143).Ada tiga tahapan Respons yang diharapkan oleh audiens sebagai calon konsumen, yaitu: (Engel, Blackwell, \& Miniard, 1995) (1) Kognitif meliputi kesadaran dan pengetahuan konsumen terhadap sebuah produk, jasa, maupun ide, (2) Afektif digambarkan dengan perasaan yang dimiliki seseorang terhadap sesuatu yang mengacu pada kesenangan seorang audience terhadap suatu produk, jasa, maupun ide. Respons afektif mengacu pada perasaan dan emosi yang dihasilkan oleh suatu rangsangan yang diterima oleh audience. Respons ini berguna dalam 
memnetukan sikap yang akan terbentuk setelah audiens melihat sebuah iklan, (3) Cenderung menunjukkan perilaku seseorang terhadap suatu produk, jasa, maupun ide yang dimiliki atau dihadapinya. Respons konatif ini mengacu pada kecenderungan perilaku pembelian.

\section{Gambar 1}

\section{Kerangka Pemikiran}

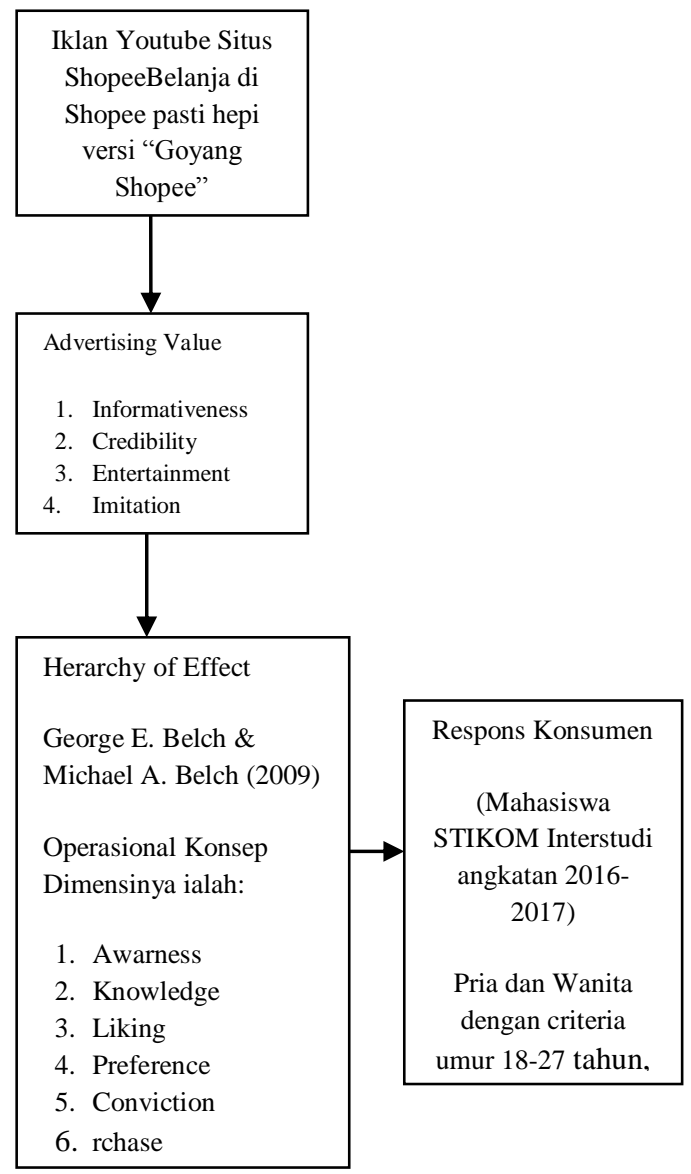

\section{METODE PENELITIAN}

\section{Paradigma Penelitian}

Paradigma penelitian ini adalah postivistik.Paradigma positivistik menganggap realitas sosial yang terjadi sebagai sesuatu yang bersifat empirik dan dapat di observasi secara nyata serta dapat di buktikan secara ilmiah. Paradigma penelitian diartikan sebagai pola pikir yang menunjukan hubungan antar variabel yang akan diteliti. Hubungan antar variabel tersebut harus dapat menjawab jenis dan jumlah rumusan masalah penelitian. Variabel-variabel itu juga menentukan hipotesis dan teknik analisis statistik yang akan digunakan. Dalam teknik analisis statistik, termasuk asumsi- asumsi dan pola pengumpulan data yang mendasari paradigma metode penelitian, Menurut (Sugiyono, 2009, p. 7).

\section{Pendekatan Penelitian}

Pada penelitian ini, pendekatan yang digunakan oleh peneliti adalah pendekatan kuantitatif yang bertujuan untuk memberikan kebenaran secara objektif, empiris, sistematis, dan teroganisir. Penelitian kuantitatif bersifat konkret dan dapat dikuantitaskan berupa angka-angka, sehingga penelitian ini bersifat objektif dimana hasilnya dapat digeneralisasikan terhadap populasi dan dapat ditafsirkan sama oleh semua orang.

Penelitian kuantitatif adalah penelitian yang menggambarkan atau menjelaskan suatu masalah yang hasilnya dapat digeneralisasikan. Dengan demikian penelitian kuantitatif tidak terlalu mementingkan aspek keluasan data sehingga data atau hasil riset dianggap merupakan reprentasi dari seluruh populasi (Kriyantono R., 2006, p. 55).

Dengan menggunakan pendekatan kuantitatif, akan diperoleh skor- skor empiris yang menginformasikan sikap responden, dimana dalam penelitian ini respondennya adalah Mahasiswa STIKOM Interstudi angkatan 2016-2017.

Metode yang digunakan peneliti adalah metode survei. Survei adalah metode penelitian yang menggunakan kuisioner sebagai instrument pengumpulan datanya. Tujuannya adalah untuk memperoleh infromasi tentang jumlah responden yang dianggap mewakili populasi tertentu.

Metode survei menurut sugiyono adalah 
penelitian yang dilakukan pada populasi besar maupun kecil, tetapi data yang dipelajari adalah data dari sampel yang diambil dari populasi tersebut, sehingga ditemukan kejadian-kejadian relative, distribusi, dan hubungan-hubungan antar variabel, sosiologis maupun psikologis (Sugiyono, 2011, p. $6)$.

\section{Jenis Penelitian}

Jenis penelitian yang digunakan adalah survei eksplanatif, karena penelitian ini melihat pengaruh antara YouTube Advertising dengan Respons Konsumen di kalangan Mahasiswa STIKOM Interstudi yang masih aktif. Sebagaimana dikatakan Burhan Bungin, jenis penelitian eksplanatif dilakukan dengan maksud menjelaskan suatu generalisasi sampel terhadap populasinya atau menjelaskan hubungan perbedaan, atau pengaruh satu variabel dengan variabel lain. Bungin dalam bukunya mengatakan bahwa penelitian eksplanatif memiliki kreadibilitas untuk mengukur, menguji hubungan sebab akibat dari dua atau beberapa variabel yang menggunakan analisis statistik infrensial. (Bungin, 2006, p. 38).

Dengan demikian, penggunaan jenis penelitian eksplanatif dalam penelitian ini bertujuan untuk menjelaskan Hubungan antara YouTube Advertising Terhadap Respons Konsumen dan Mahasiswa STIKOM Interstudi Jakarta sebagai khalayak sasarannya.

Populasi merupakan kumpulan objek penelitian. Ukuran suatu populasi dapat beragam, mulai dari jumlah yang sangat besar hingga ke jumlah sampel yang spesifik. Sebuah populasi dapat dibedakan menjadi populasi sasaran (target population), yaitu keseluruhan individu dalam areal atau wilayah atau lokasi atau kurun waktu tertentu sesuai dengan penelitian. Penetapan sampel sejumlah 100 orang didasarkan pada pernyataan Sugiono atau unit terkecil yg dapat diambil sebagai responden sampel adalah 100 orang (Sugiyono, 2011, p. 117).

Sebuah populasi dapat dibedakan menjadi populasi sasaran (target population) yaitu keseluruhan individu dalam suatu areal atau wilayah atau lokasi dalam kurun waktu tertentu dengan tujuan penelitian. Maka penentuan populasi dalam penelitian ini, adalah jumlah mahasiswa dan mahasiswi pengguna smartphone di STIKOM Interstudi angkatan 2016-2017: Jumlah populasi dalam penelitin ini adalah 344 orang.

\section{Teknik Pengumpulan Data}

Penelitian ini diperoleh dengan cara melakukan survei melalui kuisioner kepada 100 orang responden. Kuisioner adalah daftar pertanyaan yang harus diisi oleh responden. Ketentuan kuisioner dalam penelitian ini adalah sebagai berikut: (1) Kuesioner pertanyaan tertutup adalah suatu kuisioner dimana responden telah diberikan jawaban oleh periset dan responden tinggal memilih jawaban yang menurutnya sesuai dengan realitas yang dialaminya, (2) Kepustakaan. Peneliti mencari data melalui berbagai perpustakaan yang didatangi untuk menggali lebih banyak lagi informasi mengenai judul yang akan diteliti, (3) Observasi merupakan suatu proses yang kompleks, suatu proses yang tersusun dari berbagai proses biologis dan psikologis. Dua diantara yang terpenting adalah proses pengamatan dan ingatan.Teknik pengumpulan data dengan observasi digunakan bila penelitian berkenaan dengan perilaku masunia, proses kerja, gejalagejala alam, dan bila responden yang diamati tidak terlalu besar (Sugiyono, 2011, p. 203).Observasi yang dimaksud dalam penelitian ini yaitu dengan mendatangi lokasi penelitian. Tujuannya adalah untuk melihat aktivitas yang dilakukan oleh 
responden. Dalam hal ini tempat penelitiannya adalah STIKOM Interstudi Jakarta Selatan.Hal ini dilakukan agar peneliti tahu seberapa besar responden yang akan dijadikan sampel penelitian, (4) Data sekunder adalah data yang tidak langsung memberikan data kepada peneliti, Data ini diperoleh dengan menggunakan studi literatur yang dilakukan terhadap banyak buku dan diperoleh berdasarkan catatan-catatan yang berhubungan dengan penelitian, selain itu peneliti mempergunakan data yang diperoleh dari internet. (Sugiyono, 2005:62).

\section{Operasional Konsep}

Operasional adalah definisi yang menjelaskan suatu variabel dalam memberikan penjelasan dalam bentuk yang dapat diukur. Definisi operasional ini memberikan informasi-informasi yang diperlukan untuk mengukur variabel-variabel yang diteliti. Operasional konsep digunakan untuk mengukur variabel yang akan digunakan dalam penelitian, dapat menurunkan konsep-konsep yang digunakan menjadi indikator-indikator yang akan menjelaskan secara lebih padat dari konsep tersebut sehingga lebih mudah dimengerti calon responden. Pengukuran indikator-indikator ini dilakukan dengan menggunakan Skala Likert 1-5 dengan ketentuan sebagai berikut: (1) Sangat Tidak Setuju, (2) Tidak Setuju, (3) Ragu-Ragu, (4) Setuju, dan (5) Sangat Setuju.
Tabel 1. Operasional Konsep

\begin{tabular}{|c|c|c|c|}
\hline Variabel & Dimensi & Indikator & $\begin{array}{l}\text { Skala } \\
\text { Pengukura } \\
\text { n Likert }\end{array}$ \\
\hline \multirow[t]{2}{*}{ 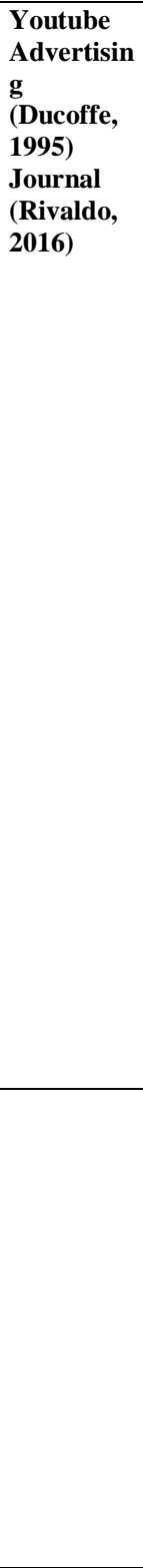 } & $\begin{array}{l}\text { Informativ } \\
\text { eness }\end{array}$ & $\begin{array}{l}\text { 1. Iklan YouTube Shopee versi } \\
\text { "Goyang Shopee"yang dibintangi } \\
\text { Via Vallen menyediakan } \\
\text { informasi yang lengkap tentang } \\
\text { kemudahan dalam mencari } \\
\text { produk idaman ketika ingin } \\
\text { belanja online } \\
\text { 2. Iklan YouTube Shopee versi } \\
\text { "Goyang Shoope"yang } \\
\text { dibintangi Via Vallen } \\
\text { menambahkan pengetahuan saya } \\
\text { tentang kelebihan Shopee } \\
\text { dibandingi situasi marketplace } \\
\text { yang lain } \\
\text { 3. Iklan Youtube Shopee versi } \\
\text { "Goyang Shopee"yang dibintangi } \\
\text { Via Vallenmenggunakan cara } \\
\text { yang kreatif dengan cara } \\
\text { bernyanyidalam menyampaikan } \\
\text { konten yang disajikan sehingga } \\
\text { dibintangi Via Vallen menarik } \\
\text { perhatian saya karena pergantian } \\
\text { setiap frame dikemasi dengan } \\
\text { sangat baik sehingga membuat } \\
\text { saya tertarik setiap melihat } \\
\text { iklannya } \\
\text { 4klan YouTube Shopee versi } \\
\text { "Goyang Shopee"Yang } \\
\text { dibintangi Via Vallen saat } \\
\text { menampilkan Via Vallen } \\
\text { bernyanyi a mempengaruhi } \\
\text { emosional saya sehingga saya } \\
\text { merasa senang karena teringat } \\
\text { terus iklan tersebut }\end{array}$ & $\begin{array}{l}\text { Sangat } \\
\text { Tidak } \\
\text { Setuju=1, } \\
\text { Tidak } \\
\text { Setuju = 2, } \\
\text { Ragu-ragu } \\
=3 \text {, Setuju } \\
=4 \text {, Sangat } \\
\text { Setuju = 5 }\end{array}$ \\
\hline & Irritation & $\begin{array}{l}\text { 1. Iklan YouTube Shopee versi } \\
\text { "Goyang Shopee" yang } \\
\text { dibintangi Via Vallen dengan } \\
\text { format unskippable menganggu } \\
\text { kegiatan saya diYouTube } \\
\text { 2. Iklan YouTube Shopee versi } \\
\text { "Goyang Shopee" yang } \\
\text { dibintangi Via Vallen dengan } \\
\text { format unskippable memaksa } \\
\text { saya untuk melihatnya } \\
\text { 3. Saya rasa iklan YouTbe Shopee } \\
\text { versi "Goyang Shopee" yang } \\
\text { dibintangi Via Vallen dengan } \\
\text { format unskippable } \\
\text { menjengkelkan }\end{array}$ & \\
\hline $\begin{array}{l}\text { Respo } \\
\text { ns } \\
\text { Konsu } \\
\text { men } \\
\text { (Y) } \\
\text { (Belch, } \\
\text { 2009) }\end{array}$ & $\begin{array}{l}\text { Kesadaran } \\
\text { (awareness) }\end{array}$ & $\begin{array}{l}\text { 1. Tayangan iklan YouTube Shopee } \\
\text { versi "Goyang Shopee"telah } \\
\text { meningkatkan pengetahuan saya } \\
\text { terhada eksistensi Shopee dalam } \\
\text { persaingan online shop } \\
\text { 2. Tayangan iklan YouTube Shopee } \\
\text { versi"Goyang Shopee" membuat } \\
\text { saya tahu bahwa ada merk jasa } \\
\text { online Shopee } \\
\text { 3. Tayangan iklan YouTube Shopee } \\
\text { ersi "Goyang Shopee" membuat } \\
\text { saya tahu akan adanya jasa } \\
\text { online shop yang memberikan } \\
\text { gratis ongkir }\end{array}$ & \\
\hline
\end{tabular}


Inter Community: Journal of Communication Empowerment Volume 1, No. 1 November 2019

\begin{tabular}{|c|c|c|c|}
\hline Variabel & Dimensi & Indikator & $\begin{array}{l}\text { Skala Pengukuran } \\
\text { Likert }\end{array}$ \\
\hline & $\begin{array}{l}\text { Pengetahu } \\
\text { an } \\
\text { (Knowledg } \\
\text { e) }\end{array}$ & $\begin{array}{l}\text { 1. Iklan YouTube Shopee versi "Goyang } \\
\text { Shopee" membuat saya mengerti } \\
\text { tentang keunggulan Shopee } \\
\text { 2. Iklan YouTube Shopee versi "Goyang } \\
\text { Shopee" membuat saya mengerti } \\
\text { tentang manfaat jasa online Shopee } \\
\text { 3. Iklan Youtube Shopee versi "Goyang } \\
\text { Shopee" membuat saya mengerti } \\
\text { tentang produk yang diiklankan di } \\
\text { Shopee }\end{array}$ & \\
\hline & $\begin{array}{l}\text { Kesukaan } \\
\text { (Liking) }\end{array}$ & $\begin{array}{l}\text { 1. Iklan YouTube Shopee versi "Goyang } \\
\text { Shopee"membuat saya menonton iklan } \\
\text { tersebut sampai selesai } \\
\text { 2. Iklan YouTube Shopee versi "Goyang } \\
\text { Shopee" menarik perhatian saya karena } \\
\text { janji yang disampaikan iklan tersebut } \\
\text { bahwa Shopee mampu menjadi online } \\
\text { shop terpercaya sehingga dapat } \\
\text { memenuhi kebutuhan belanja online } \\
\text { saya } \\
\text { 3. Iklan Youtube Shopee versi "Goyang } \\
\text { Shopee" membuat saya menyukai merk } \\
\text { tersebut karena penyampaian pesan } \\
\text { yang dikemas secara baik sehingga } \\
\text { membuat saya tertarik belanja di } \\
\text { Shopee }\end{array}$ & \\
\hline & \begin{tabular}{|l} 
Pilihan \\
(Preference)
\end{tabular} & $\begin{array}{l}\text { 1. Iklan YouTube Shopee versi "Goyang } \\
\text { Shopee" membuat saya memilih merek } \\
\text { Shopee disbanding merek pesaing } \\
\text { karena lebih banyak diskon yang } \\
\text { ditawarkan } \\
\text { 2. Iklan YouTube Shopee versi "Goyang } \\
\text { Shopee" membuat saya memilih untuk } \\
\text { mencoba jasa took online shopee } \\
\text { 3. Iklan YouTube Shopee versi "Goyang } \\
\text { Shopee" membuat saya memilih merek } \\
\text { Shopee karena jaminan gratis ongkir }\end{array}$ & \\
\hline & $\begin{array}{l}\text { Keyakinan } \\
\text { (Convictio } \\
\text { n) }\end{array}$ & $\begin{array}{l}\text { 1. Tayangan iklan YouTube Shopee } \\
\text { "Versi Goyang Shopee" membuat saya } \\
\text { yakin dengan merek tersebut } \\
\text { 2. Tayangan iklan Youtube SHopee versi } \\
\text { "Goyang Shopee" membuat saya yakin } \\
\text { dengan manfaat goyang shopee yang } \\
\text { shopee tawarkan karena memberikan } \\
\text { koin yang bisa ditukarkan sebagai } \\
\text { potongan belanja } \\
\text { 3. Tayangan iklan YouTube Shopee versi } \\
\text { "Goyang Shopee" membuat saya yakin } \\
\text { untuk merekomendasikan jasa Shopee } \\
\text { kepada teman-teman saya }\end{array}$ & \\
\hline & $\begin{array}{l}\text { Purchase } \\
\text { (Pembelia } \\
\text { n) }\end{array}$ & $\begin{array}{l}\text { 1. Saya akan mempertimbangkan untuk } \\
\text { membeli barang di Shopee setelah } \\
\text { menyaksikan Iklan YouTube Shopee } \\
\text { versi "Goyang Shopee" } \\
\text { 2. Iklan YouTube Shopee versi "Goyang } \\
\text { Shopee" membuat saya berniat } \\
\text { menjadikan Shopee sebagai pilihan } \\
\text { utama dalam berbelanja barang online } \\
\text { karena banyak pilihan barang yang } \\
\text { Shopee tawarkan } \\
\text { 3. Saya akan membeli produk di Shopee } \\
\text { setelah menyaksikaniklan YouTube } \\
\text { Shope versi "Goyang Shopee" }\end{array}$ & \\
\hline
\end{tabular}




\section{PEMBAHASAN}

Uji validitas ini menggunakan metode Kasier-Meyer-Olkin-Measure of Sampling Adequency (KMO and barlett's test). Analisis faktor adalah suatu Teknik statistik untuk mengidentifikasikan jumlah factor yang relative kecil dapat digunakan untuk mengambarkan beberapa variabel yang berhubungan.

Tabel 2. KMO and Bartlett's Test

\begin{tabular}{|ll|l|}
\hline \multicolumn{2}{|l|}{ Kaiser-Meyer-Olkin Measure of } & .864 \\
Sampling Adequacy. & \\
Bartlett's Test of & Approx. Chi- & 1741.43 \\
Sphericity & Square & 2 \\
& df & 153 \\
& Sig. & .000 \\
\hline
\end{tabular}

Berdasarkan table diatas dapat diketahui bahwa variable YouTube Advertising dapat dikatakan valid karena memiliki nilai KMO di atas 0,5 yaitu 0,886. Berarti variable YouTube Advertising layak diikutsertakan ke dalam uji berikutnya.

Tabel 3. KMO and Bartlett's Test

\begin{tabular}{|ll|l|}
\hline \multicolumn{2}{|l|}{ Kaiser-Meyer-Olkin Measure of } & .864 \\
Sampling Adequacy. & \\
Bartlett's Test of & Approx. Chi- & 1741.43 \\
Sphericity & Square & 2 \\
& df & 153 \\
& Sig. & .000 \\
\hline
\end{tabular}

Berdasarkan tabel di atas,dapat ditentukan bahwa variabel Respons Konsumen dapat dikatakan valid karena memiliki nilai KMO di atas 0,5 yaitu 0,864. Berarti variabel Respons Konsumen layak diikutsertakan ke dalam uji berikutnya.

Setelah dilakukan uji validitas dan didapatkan hasil yang valid, maka tahap selanjutnya ialah menguji tingkat reliabilitas dari dimensi beserta indicator- indikatornya. Analisa reliabilitas merujuk pada suatu pengertian bahwa suatu instrument penelitian cukup dapat dipercaya untuk dapat digunakan sebagai alat pengumpulan data, karena instrument tersebut sudah cukup baik. Dalam penelitian ini, pengujian reliabilitasnya menggunakan Cronbach Alpha.

Tabel 4.

Reliability Statistic

\begin{tabular}{|c|c|c|}
\hline & & \\
& Cronbach's & \\
& Alpha Based & \\
Cronbach's & on & \\
Alpha & Items & N of Items \\
\hline .85 & .84 & 12 \\
3 & 7 & \\
\hline
\end{tabular}


Berdasarkan table di atas, dapat diketahui seluruh pernyataan yang diajukan dalam variabel Iklan YouTube memiliki nilai Cronbach Aplha diatas 0,6 yaitu sebesar 0,853 . Artinya 12 pernyataan yang ada dalam uji reliabilitas pada variabel $\mathrm{X}$ dapat dipercaya sebagai alat pengumpulan data dalam penelitian ini.

Tabel 5.

Reliability Statistic

\begin{tabular}{|c|c|c|}
\hline & $\begin{array}{c}\text { Cronbach's } \\
\text { Alpha Based } \\
\text { on }\end{array}$ & \\
& Standardized & N of \\
Cronbach's & Items & Items \\
Alpha & .960 & 18 \\
\hline .958 & & \\
\hline
\end{tabular}

Berdasarkan table di atas, dapat diketahui bahwa seluruh pernyataan yang diajukan dalam variabel Respons Konsumen memiliki nilai Cronbach Alpha di atas 0,6 yaitu sebesar 0,958. Artinya 18 pernyataan yang ada dalam uji reliabilitas variabel Respons Konsumen dapat dipercaya sebagai alat pengumpulan data dalam penelitian ini.

Tabel 6.

Model Summary

\section{a. Predictors: (Constant), Variabel X (Youtube Advertising)}

Berdasarkan table di atas, nilai korelasi antara variabel Iklan YouTube dan Respons Konsumen adalah sebesar 0,721. Bila mengacu pada interval koefisien korelasi pada tabel tersebut, maka dapat diartikan nilai tersebut memiliki hubungan yang Kuat. Sedangkan koefisien determinasi adalah sebesar 0,520 yang berarti sebesar 52\% variabel YouTube Advertising mampu menjelaskan variance dari variabel respons konsumen. Sementara sisanya dipengaruhi oleh faktor lain.

Tabel 7. ANOVA

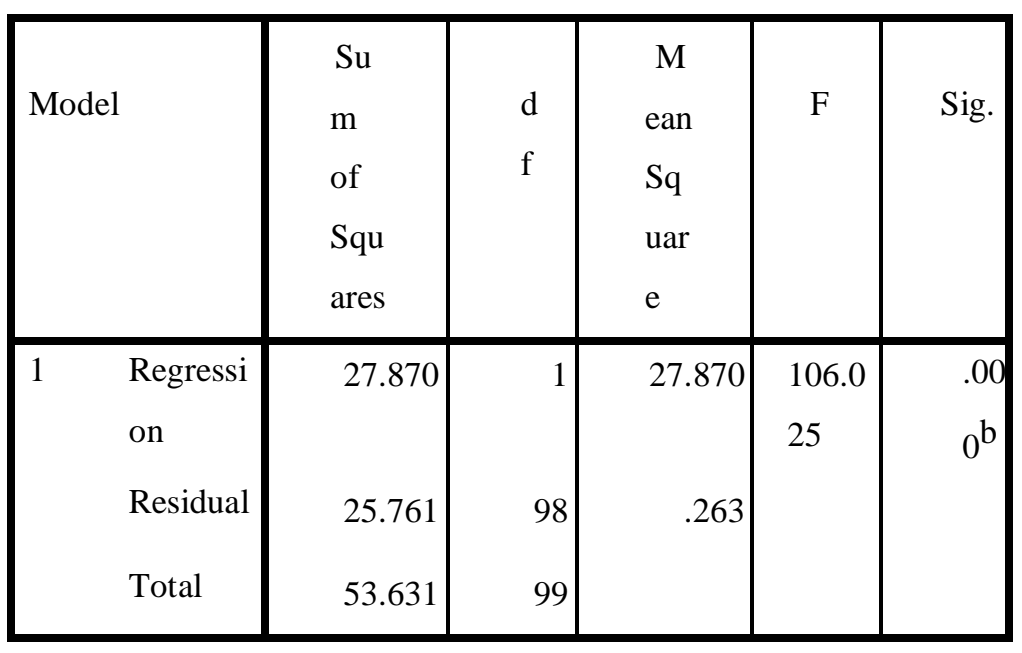

Berdasarkan tabel di atas. Dapat disimpulkan bahwa nilai signifikansi sebesar 0,000 yang berarti tingkat signifikansi variabelnya tinggi dan memenuhi persyaratan yaitu $<0,05$ sehingga dapat digunakan untuk menjelaskan pengaruh antara variabel independent YouTube Advertising dengan variabel dependent Respons Konsumen adalah terdapat hubungan yang linier. 


\section{KESIMPULAN}

Ada pengaruh dari YouTube Advertising online shop Shopee terhadap respons konsumen. Dan terdapat pengaruh yang kuat dari Youtube Advertising Shopee terhadap respons konsumen. Dilihat dari hasil analisa yang diperoleh tanggapan responden Youtube Advertising positif. Jika dilihat dari garis kontinum pada variabel $\mathrm{X}$ (YouTube Advertising) nilai mean tertinggi pada dimensi Entertainment dengan pernyataan Iklan YouTube Shopee versi "Goyang Shopee" yang dibintangi Via Vallen saat menampilkan Via Vallen bernyanyi mempengaruhi emosional saya sehingga saya merasa senang karena teringat terus iklan tersebut dan pada variabel Y (Respons Konsumen) nilai mean tertinggi pada dimensi Awareness mengenai pernyataan Tayangan iklan YouTube Shopee versi "Goyang Shopee"membuat saya tahu akan adanya jasa online shop yang memberikan gratis ongkir maka dapat dikatakan bahwa iklan YouTube Shopee versi "Goyang Shopee" dapat tersampaikan dengan baik kepada respondennya. Hasil penelitian ini menunjukkan responden percaya dan setuju bahwa aplikasi Shopee dapat mempermudah responden dalam berbelanja online shop.

\section{DAFTAR PUSTAKA}

Bungin, Burhan. 2011. Metodologi Penelitian Kuantitatif. Jakarta: Kencana.

Dominick, J.R. 2008. The Dynamics of Mass Communication: Media in The Digital Age. New York: McGraw - Hill Higher.

Engel, James. F, Roger. D Blackwell, and Paul. W
Jakarta: Binarupa Aksara.

Jenkins, H. 2007. Nine Propositions Towards a Cultural Theory of Youtube.

Kaplan, Andreas, and Michael Haenlein. 2010. Users of The World, Unite! The Challenges and Opportunities of Social Media. Business Horizons: Terjemahan Istiwijayanti.

Kotler, Philip. 2005. Manajemen Pemasaran.

Jakarta: Gramedia.

Kotler, Philip, and Kevin Lane Keller. 2009. Marketing Management. Jakarta: Pearson Prentice Hall.

Kotler, Phillip. 2000. Manajemen Pemasaran. Jakarta: Erlangga.

Kriyantono, Rahmat. 2006. Teknik Praktis Riset Komunikasi. Jakarta: PT. Kencana Perdana.

Lamb, Charles. 2001. Pemasaran. Jakarta: Salemba Empat.

Lee, Monle, and Johnson Carla. 2004. PrinsipPrinsip Pokok Periklanan Dalam Perspektif Global. Jakarta: Prenada Media.

Moriarty, S. E., Mitchell, N., \& Wells, W. D. 2015. Advertising and IMC: Principles and practice. Boston: Pearson.

Shimp, Terence A. 2003. Periklanan Promosi \& Aspek Tambahan Komunikasi Pemasaran Terpadu, Jilid 1 (Edisi 5).

Jakarta: Erlangga.

Miniard. 1994. Perilaku Konsumen. 
Soemanegara, R. Dermawan. 2006. Strategic

Marketing Communication. Bandung:

Alfabeta.

Soerjabrata, Soemadi. 1980. Psikologi

Pendidikan. Yogyakarta: Rake Press.

Sugiyono. 2016. Metode Penelitian Kuantitatif

Kualitataif dan Kombinasi (Mixed).

Bandung: Alfabeta.

\section{-. 2011. Metode Penelitian Kuantitatif}

Kualitatif dan R\&D. Bandung: Alfabeta.

-. 2009. Metode Penelitian Kuantitatif,

Kualitatif dan R\&D. Bandung: Alfabeta.

Suhandang, Kusnadi. 2010. Periklanan

Manajemen, Kiat dan Strategi. Jakarta:

Nuansa.

Sumarwan, Ujang. 2011. Perilaku Konsumen:

Teori dan Penerapannya dalam

Pemasaran. Bogor: Ghalia Indonesa. 